\title{
GREEN INITIATIVES OF SBI: A CUSTOMER-CENTRIC STUDY
}

\begin{tabular}{|c|c|}
\hline Neeraja T S & $\begin{array}{c}\text { Assistant Professor, Dept of Commerce and } \\
\text { Research Centre, St Albert's College } \\
\text { (Autonomous), Ernakulam, Kerala }\end{array}$ \\
\hline Dr Raji Joseph & $\begin{array}{c}\text { Associate Professor (Retd) and Research Supervisor, } \\
\text { St Xavier's College for Women, Aluva, Ernakulam }\end{array}$ \\
\hline
\end{tabular}

\begin{abstract}
DOI No: 10.36713/epra6314

Article DOI URL: https://doi.org/10.36713/epra6314

Green banking is the topic of discussion in the current era of global warming and climate change. India banking system has taken the concept of green banking into consideration and the circular issued by RBI in 2013 regarding green banking is the proof of its relevance. SBI is a bank in the public sector which has taken green banking into next level. The initiatives taken by the bank in implementing green banking is remarkable and this study intends to conduct an indepth study about the green products offered by the bank. The article also analyses the concept of green banking from the side of customers. The awareness level of customers regarding various green product is looked into. An in-depth analysis of the benefits and satisfaction of green banking is also done from the perspective of customers.
\end{abstract}

KEYWORDS: Green Banking, Sustainable Banking, Green Products, Paperless Banking

\section{INTRODUCTION}

During the last 41 years since 1969, tremendous changes have taken place in the banking industry. Banks introduced innovative activities and new types of services to satisfy the needs of customers. Mobilisation of savings massive branch expansion in the rural areas and diversification of credit facilities to neglected areas etc... have resulted in widening of financial structure and development in banking sector. During the last 25 years the world has become aware of environmental problems like environmental pollution, acid rain, global warming, ozone depletion etc. Government has taken several measures to overcome the situations. Here arises the concept of "sustainable development." Sustainable development means meeting the needs of present generation wit out compromising the ability of future generation.

The financial sector of economy plays a significant role in the economic development of a country and in India the banking sector being a significant part of the financial system of the country, its role in sustainable development become very obvious. Banks plays a significant role in increasing the environmental protection. For the protection of environment banks adopted the concept of sustainable banking.

Institute for Development and Research in Banking Technology defines Green banking as "Green banking is an umbrella term referring to practices and guidelines that make banks sustainable in economic, environmental, and social dimensions. 
It aims to make banking processes and the use of IT and physical infrastructure as efficient and effective as possible, with zero or minimum impact on the environment".

Banking sector has undergone significant developments and innovations in past recent. Most of the banks are provide lots of sustainable services to the customers such as online banking, mobile banking, green card facilities etc. This study focuses on the green banking initiatives by SBI banks and to know the satisfaction level of customers regarding sustainable banking.

\subsection{SBI AND GREEN BANKING}

The State Bank of India (SBI) is an Indian multinational public sector banking and financial services company. It is a Govt.-owned corporation headquartered in Mumbai, Maharashtra. The company is ranked $216^{\text {th }}$ on the Fortune Global 500 list of goal's biggest corporation as of 2017.It is the largest Bank in India with a 23\% market shares in asset, besides a share of $1 / 4^{\text {th }}$ of the total loan and deposit market. Green banking products and services provided by SBI are:

\subsubsection{GREEN CHANNEL COUNTERS}

In green channel counters the customers need not fill up any pay-in slips or draw cheques for depositing or withdrawing money from their accounts, saving paper, and thereby contributing to the concept of green banking. At green banking channel counter, there is a Point of Sale Machine (POS), on which the customer swipes his card.

\subsubsection{SELF SERVICE KIOSKS}

An interactive kiosk is a computer terminal featuring specialized hardware and software that provides access to information and applications for communication, commerce, entertainment or education. Integration of technology allows kiosk to perform a wide range of functions, evolving into Self Service Kiosks.

\subsubsection{GREEN REMIT CARDS}

SBI Green Remit Cards is a simple Magstripe based card without PIN. The product is targeted to facilitate non-home cash deposit transactions to be routed through green channel counter/cash deposit machine.

\subsubsection{SMART PAY OUT CARD}

SBI smart pay out card is a prepaid card issued in Indian rupees in association with VISA. It is an ideal product for making periodical payments like salary, wages, commission, etc. and also can be issued as an add-on card for the existing account holders. SBI Smart Pay out Card can be used for cash withdrawal at ATMs, for purchase transactions at merchant establishment and for e-commerce transaction i.e., for online payment.

\subsubsection{GREEN FINANCING}

The bank is providing long term loans at concessionary rate of interest for renewables energy project to encourage reduction of greenhouse gases. It also provides finance for organic farming including financing of bio fertilizers, vermin-compost units etc. to prevent degradation of previous arable land and pollution of water from the abuse of chemical fertilizers/ pesticides /insecticides.

\subsubsection{ONLINE BANKING}

Online banking, also known as internet banking, is an electronic payment system that enables customers of a bank or other financial institution to conduct a range of financial transactions through the financial institution's website. Internet banking software provides personal and corporate banking services offering features such as viewing account balances, obtaining statements, checking recent transactions and making payments.

\subsubsection{MOBILE BANKING}

Mobile banking is a service provided by a bank or other financial institutions that allows its customers to conduct financial transactions remotely using a mobile device such as a smart phone or tablet.

\section{PROBLEM STATEMENT}

Banking is not confined to the traditional business of accepting deposits and lending money. Though banks do not have direct impact on nature through their business, they are the major source of finance for the polluting business units. Therefore, banks have the responsibility to ensure that they do not fund environmentally polluting business. This is the core objective of green banking. Banks implement green banking through various green banking products. This study is conducted to understand the concept of green banking and the initiatives taken by SBI- largest public sector bank to implement green banking. The attitude of customers towards green banking is also analysed.

\section{OBJECTIVES}

- To know the various green products and services provided by SBI under green banking.

- To check the awareness level of customers about the concept of green banking.

- To know the sources of information regarding green banking from the perspective of customers.

- $\quad$ To understand the benefits to the customers through green banking initiatives of SBI. 
- To know the satisfaction level of customers regarding green banking activities of SBI.

\section{RESEARCH METHODOLOGY}

Sources of data: Both primary and secondary data were used for the purpose of study. Primary data was obtained through surveys conducted in Kochi city through questionnaires. Secondary data for the study was collected from internet, newspapers, magazines, books etc.

Sample size: A sample of 100 respondents were selected from Kochi city through convenience sampling technique.

Tools for analysis: Pie-chart, bar chart, percentage are the tools used for analysis.

\section{LIMITATION OF STUDY}

1. Time constrains was the limitation. Due to short period of research in-depth study could not be made.

2. The study was restricted to Cochin City. So the sample collected may not be representative.

3. The information provided by people may be biased

\section{LITERATURE REVIEW}

Gopi, S. (2016) identified the role of SBI in environment protection. An analysis of the initiatives of SBI was conducted. The study was conducted from the perspective of employees and customers. The researcher concluded that banking sector has a major role in environment protection. IT has a major role in implementing green banking. Green initiatives of the bank help in improving the awareness of the customers towards sustainable development.

Katyal \& Nagpal. (2014) conducted a study on the overall green initiatives of the banking sector in India. Prominent banks from the major sectors were taken for study which includes ICICI, IDBI, SBI, Axis bank and SIDBI. Insta banking, Vehicle finance, Carbon footprint calculator, solar powered ATMs, Green home loan schemes SIDBI's financing schemes for energy saving etc... are some of the green banking products and services offered by the leading banks. The researchers concluded their study that the banks should improve the use of environmental information in relating to decisions regarding investment and credit. This will certainly help them to improve their environmental performance.

Bihari \& Pandey, (2015) was of the opinion online mode of banking is the better way to green and helps in environmental protection. The prominent CSR activities implemented by SBI are Distribution of lakhs of electric fans and water filters in schools in India, financing Save the Child Projects, and promoting green banking by change in traditional paper banking to card based banking and installation of wind mills. Green mortgages, wind mills, green credit cards, power saving equipments, mobile banking, etc... are green banking products offered by SBI.SBI also go greens with home loans. The case study also studies how the other banks implementing the concept of green banking. As a conclusion the study states that, today many Indian banks are making efforts to "Go Green" through offering various green products and services to their customers. The concept of green banking will be mutually beneficial to the banks, industries and the economy.

Raj \& Rajan, (2017) explained green banking as a form of banking which enhances lesser utilisation of natural resources and maximum reduction in carbon footprints/usage of papers.in recent, banks adopting more and more green practices to protect the environment. Green banking practices are one of the important developments in the banking sector and which needs maximum awareness on customers. The researcher found the awareness of customers regarding green banking activities and to know the satisfaction level of customers of SBI. Conclusion made through this study is that the implementation of various green banking products is not sufficient for creation of better environment. Green banking is a CSR of every bank through these implementation customers are carrying out their banking transactions in environment friendly manner.to adopt and improve more green banking activities banks should receive the support of Govt., NGOs, business organizations and consumers.

\section{ANALYSIS AND INTERPRETATION}

7.1 AWARENESS LEVEL OF GREEN BANKING ACTIVITIES

Table 1

\begin{tabular}{|c|c|}
\hline $\begin{array}{c}\text { AWARENESS OF GREEN } \\
\text { BANKING ACTIVITIES }\end{array}$ & NO.OF RESPONDENTS \\
\hline Yes & 76 \\
\hline No & 24 \\
\hline Total & 100 \\
\hline Source: Primary Data
\end{tabular}

From the above table it shows that only $76 \%$ of the total respondents are aware about the sustainable banking activities. 


\subsection{SOURCE OF INFORMATION}

Fig 1

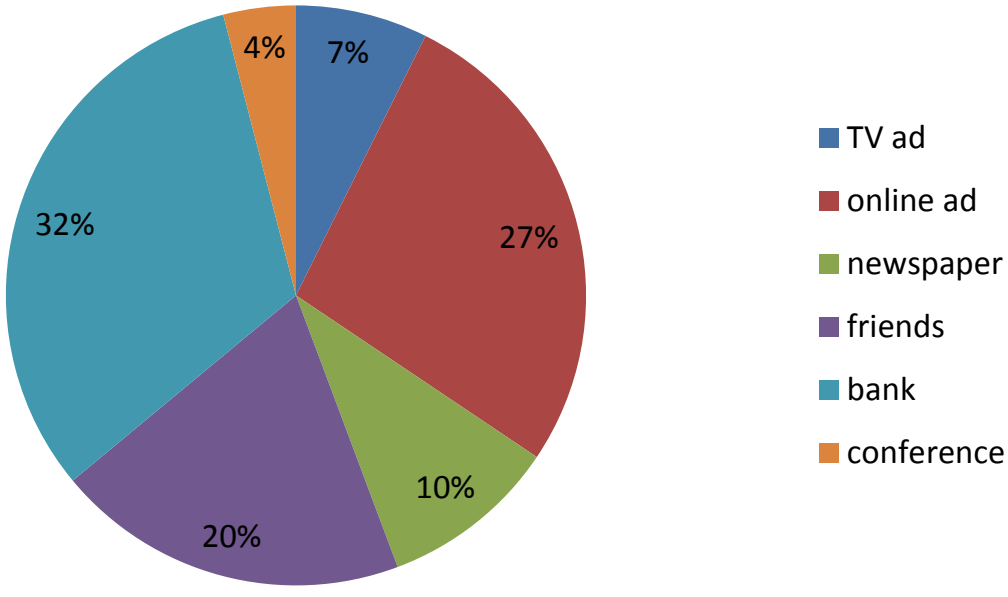

The above figure shows that $7.3 \%$ of the respondents get information about green banking activities through TV ads, $26.8 \%$ get information through online ads, $9.8 \%$ get information through newspapers and magazines, $19.5 \%$ get information through friends, $31.7 \%$ get information from banks and $4 \%$ through conference.

\subsection{AWARENESS LEVEL OF SUSTAINABLE SERVICES}

TABLE 2

\begin{tabular}{|c|c|c|c|}
\hline SERVICES & HIGHLY AWARE & AWARE & NOT AT ALL \\
\hline Online banking & $60 \%$ & $30 \%$ & $10 \%$ \\
\hline Mobile banking & $70 \%$ & $20 \%$ & $10 \%$ \\
\hline Green deposits & $5 \%$ & $30 \%$ & $55 \%$ \\
\hline Green mortgages and loans & $5 \%$ & $40 \%$ & $30 \%$ \\
\hline Green credit cards & $10 \%$ & $60 \%$ & $70 \%$ \\
\hline $\begin{array}{c}\text { Green rewards checking } \\
\text { accounts }\end{array}$ & $5 \%$ & $25 \%$ & $80 \%$ \\
\hline Green CDs & $5 \%$ & $15 \%$ & $65 \%$ \\
\hline Power saving equipment & $15 \%$ & $20 \%$ & $65 \%$ \\
\hline Green financing & $10 \%$ & $25 \%$ & \\
\hline
\end{tabular}

Source: Primary Data

The above table shows that $70 \%$ of the respondents are highly aware about mobile banking, followed by online banking $(60 \%) .80 \%$ of the

respondents are not aware of Green CDs. $65 \%$ of the respondents are not aware of Power saving equipment, Green financing and Green deposits.

\subsection{SATISFACTION LEVEL OF OVERALL GREEN BANKING ACTIVITIES}

Fig: 2

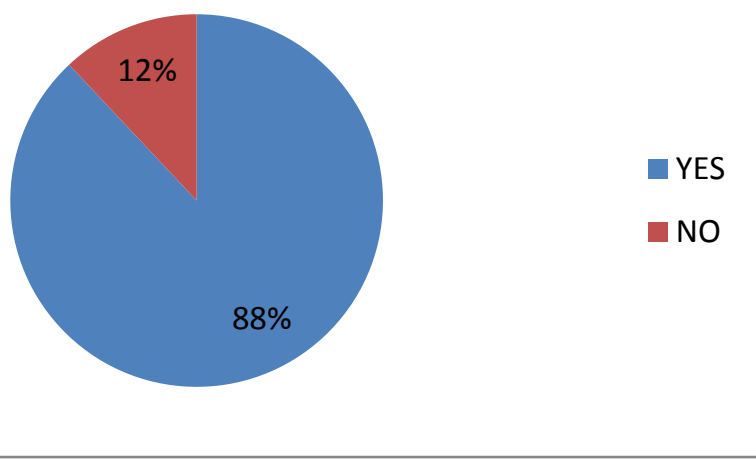


From the above chart, it is clear that $88 \%$ of the total respondents satisfied with overall green banking activities and rest of them not satisfied.

\subsection{LEVEL OF SATISFACTION}

Table:3

\begin{tabular}{|c|c|c|c|c|c|}
\hline SERVICES & $\begin{array}{c}\text { HIGHLY } \\
\text { SATISFIED }\end{array}$ & SATISFIED & NO OPINION & DISSATISFIED & $\begin{array}{c}\text { HIGHLY } \\
\text { DISSATISFIED }\end{array}$ \\
\hline ONLINE BANKING & $32 \%$ & $50 \%$ & $18 \%$ & $0 \%$ & $0 \%$ \\
\hline MOBILE BANKING & $46 \%$ & $40 \%$ & $14 \%$ & $0 \%$ & $0 \%$ \\
\hline GREEN DEPOSITS & $6 \%$ & $28 \%$ & $66 \%$ & $0 \%$ & $0 \%$ \\
\hline $\begin{array}{c}\text { GREEN MORTGAGES AND } \\
\text { LOANS }\end{array}$ & $6 \%$ & $20 \%$ & $74 \%$ & $0 \%$ & $0 \%$ \\
\hline $\begin{array}{c}\text { GREEN CREDIT CARDS } \\
\text { GREEN REWARD CHECKING } \\
\text { ACCOUNTS }\end{array}$ & $6 \%$ & $32 \%$ & $62 \%$ & $0 \%$ & $0 \%$ \\
\hline GRREN CDS & $6 \%$ & $16 \%$ & $78 \%$ & $0 \%$ & $0 \%$ \\
\hline POWER SAVING EQUIPMENTS & $8 \%$ & $22 \%$ & $70 \%$ & & $0 \%$ \\
\hline GREEN FINANCE & $6 \%$ & $30 \%$ & $64 \%$ & $0 \%$ & $0 \%$ \\
\hline
\end{tabular}

Source: Primary Data

The above table shows that $32 \%$ of the total respondents are highly satisfied of online banking, $50 \%$ are satisfied and $18 \%$ has no opinion. In mobile banking, $45 \%$ are highly satisfied, $40 \%$ are satisfied and $15 \%$ has no opinion. In case of other services satisfaction level of customers is low. Around $80 \%$ of the total respondents have no opinion.

\subsection{BENEFITS FROM GREEN BANKING ACTIVITIES}

Fig : 3

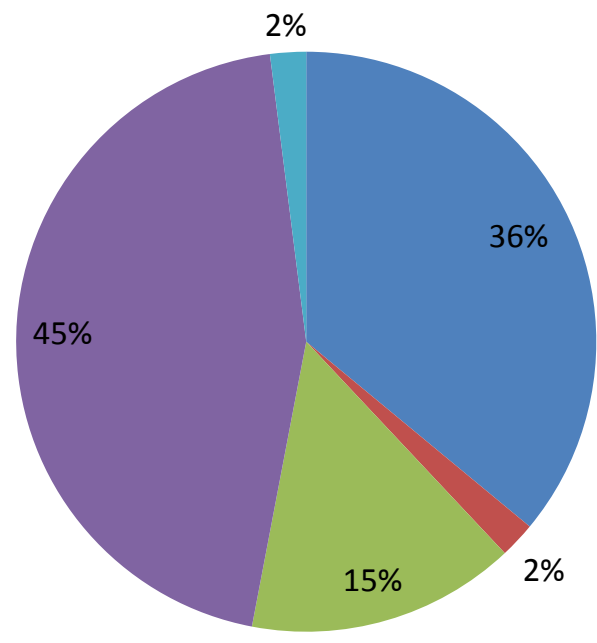

SAVE COST

- LOANS AT CONCESSIONAL RATE

PAPERLESS BANKING

SAVES TIME

ENVIRONMENT PROTECTION
The above figure shows that $45 \%, 36 \%, 15 \%, 2 \%, 2 \%$ of the total respondents benefited from sustainable services because it saves time, saves cost, paperless transactions, loans at concessional rates and environment protection respectively.

\section{FINDINGS}

$>$ Majority of the respondents are aware about the various green initiatives of SBI.

$>$ The analysis of the awareness level of various sustainable services by the respondents shows that majority of the respondents are highly aware of mobile banking and online banking. The respondents are least aware about green deposits and green CDs

$>88 \%$ of the total respondents are satisfied with overall green banking activities.

$>$ Respondents are highly satisfied with online banking and mobile banking.

$>$ Through green banking activities the customers can save their time and cost.

\section{SUGGESTIONS}

$>$ The banks may take necessary steps to improve the awareness level of customers regarding green banking. 
Banks should take up measures to improve the awareness level of customers regarding green deposits and green CDs.

$>$ Banks should take up measures to improve the satisfaction level of their customers.

\section{CONCLUSION}

The financial sector of economy plays a significant role in the economic development of a country and in India the banking sector being a significant part of the financial system of the country, its role in sustainable development become very obvious. Banks plays a significant role in increasing the environmental protection. For the protection of environment banks adopted the concept of sustainable banking. The study can be concluded by inferring that customers' awareness on the concept of green banking is good. But in-depth analysis of the awareness on individual green banking products offered by the bank showed that respondents are aware of mobile and online banking. The level of awareness for green deposits, green CDs and green rewards are very poor. SBI should not just confine their responsibility towards launching green banking products, but measures should be adopted to improve the awareness of such products among the customers.

\section{REFERENCE}

1. Gopi, S. (2016). A Study on the impact of Green Banking in environmental protection. International Journal of Advance Research and Innovative Ideas in Education, 1(4), 382-388.

2. Katyal, S., \& Nagpal, S. (2014). Role of Green Banking in Sustainable Development of India. International Journal of 360 Management Review, 2(01), 2320-7132.

3. Bihari, S. C., \& Pandey, B. (2015). Green banking in India. Journal of Economics and International Finance, 7(1), 1-17.

4. Raj, D. G. P., \& Rajan, D. A. P. (2017). A Study on the Customer Awareness on Green Banking Initiatives. Intercontinental Journal of Finance Research Review, 5(7), 54-65.

5. Annual Report 2017-18. (2018). Retrieved from www.sbi.co.in

6. Namita Rajput. Ruchika Kaura, MS., Akanksha Khanna, Ms. (2013).Indian Banking Sector towards Sustainable Growth: A Paradigm Shift .International Journal of Academic Research in Business and Social Sciences January. Vol. 3, No. 1 ISSN: 2222-6990

7. Sarita Bahl. (2012).Role of Green Banking in Sustainable Growth. International Journal of Marketing. Financial Services and Management Research. Vol.1 No.2, ISSN 22773622. 